\title{
Bemerkenswerte Publikationen von ÖGUM-Mitgliedern: Ultraschall mit österreichischem Beitrag ...
}

Röfo. 2018 Jul 2. doi:10.1055/a-0639-5713

[Epub ahead of print]

Ultrasonography for the Diagnosis of Carpal Tunnel Syndrome in Diabetic Patients: Missing the Mark?

Steinkohl $F^{1}$, Loizides $A^{1}$, Gruber $L^{1}$, Karpf $M^{1}$, Mörsdorf $G^{2}$, Gruber ${ }^{2}$, Glodny $B^{1}$, Löscher $W^{3}$, Gruber $\mathrm{H}^{1}$

1 Department of Radiology, Medical University Innsbruck, Austria

2 Department of Vascular Surgery, Medical University Innsbruck, Austria

3 Department of Neurology, Medical University Innsbruck, Austria

Material und Methoden Es wurden 233 Handgelenke von 153 Patienten untersucht. Die Querschnittsfläche (CSA) des Nervus medianus wurde mit einem Linearschallkopf erhoben. Die WFR wurde errechnet.

Ergebnisse Patienten mit DM und CTS hatten signifikant niedrigere WFR-Werte als Patienten ohne DM mit CTS $(p=0,002)$. Es gab keinen Unterschied zwischen der WFR von Patienten mit DM und ohne CTS und von Patienten mit DM und mit CTS $(p=0,06)$. Die diagnostische Genauigkeit zwischen Patienten mit DM und mit CTS und Patienten mit DM und ohne CTS war mit der WFR niedrig (ROC AUC $=0,630$, $95 \%$ Cl 0,541-0,715, $p=0,011)$.

Schlussfolgerung Die Ergebnisse dieser Arbeit legen nahe, dass die WFR bei Patienten mit DM und CTS eine niedrige diagnostische Genauigkeit hat. Daher sollte sie bei diesen Patienten nur mit Vorsicht verwendet werden.
Kernaussagen Die diagnostische Genauigkeit der WFR ist bei Diabetikern niedrig. Die WFR sollte bei Patienten mit DM nicht verwendet werden. Die sonografische Beurteilung des Nervus medianus sollte bei Patienten mit DM den Schwerpunkt auf morphologische Veränderungen legen.

Purpose Diabetes mellitus (DM) and carpal tunnel syndrome (CTS) are common pathologies. The diagnosis of CTS can be facilitated by the use of an ultrasoundbased wrist-to-forearm ratio (WFR) of the nerve diameter. However, the applicability of WFR in DM-patients is not yet clear.

Materials and Methods 233 wrists of 153 patients were examined. Cross-sectional areas (CSA) of the median nerve were obtained using a linear array probe. The WFR was calculated.

Results Diabetics with CTS had significantly lower WFR values than non-diabetics with CTS $(p=0.002)$. There was no difference between the WFR of diabetics with and without CTS $(p=0.06)$. The diagnostic accuracy between diabetics with and without CTS was low for measurements of WFR (ROC AUC $=0.630,95 \% \mathrm{Cl} 0.541-0.715$, $\mathrm{p}=0.011)$

Conclusion Our findings suggest that the WFR has a low diagnostic accuracy in diabetic patients with CTS and should be used with caution in those patients.

Semin Musculoskelet Radiol. 2018 Jul; 22(3): 344 - 353. doi:10.1055/s-00381641577. Epub 2018 May 23
Nerve Entrapment Syndromes at the Wrist and Elbow by Sonography.

Klauser AS ${ }^{1}$, Buzzegoli $T^{1}$, Taljanovic $\mathrm{MS}^{2}$, Strobl $S^{1}$, Rauch $S^{1}$, Teh $J^{3}$, Wanschitz J ${ }^{4}$, Löscher $W^{4}$, Martinoli $C^{5}$.

1 Department of Radiology, Medical University Innsbruck, Innsbruck, Austria

2 Department of Medical Imaging, University of Arizona, College of Medicine, Banner-University Medical Center, Tucson, Arizona

3 Department of Radiology, Nuffield Orthopaedic Centre, Headington, Oxford, United Kingdom

4 Department of Neurology, Medical University Innsbruck, Innsbruck, Austria

5 Cattedra "R" di Radiologia-DICMI, Università di Genova, Genova, Italy

\section{Abstract}

Nerve entrapment syndromes of the upper extremity are associated with structural abnormalities or by an intrinsic abnormality of the nerve. Nerve entrapment syndromes generally have a typical clinical presentation, and findings on physical examination and in conjunction with electrodiagnostic studies imaging is used to evaluate the cause, severity, and etiology of the entrapment. With the development of highfrequency linear array transducers (12$24 \mathrm{MHz}$ ), ultrasound (US) is incomparable in terms of spatial resolution to depict morphological aspects and changes in nerves. US can identify the abnormalities causing entrapment, such as fibrous bands, ganglia, anomalous muscles, and osseous deformities, with the advantage of dynamic assessment under active and passive examination. US is a unique diagnostic modality that allows superb visualization of both 
large and small peripheral terminal nerve branches of the upper extremity and enables the correct diagnosis of various nerve entrapment syndromes.

Thyroid Res. 2018 May 9; 11: 3. doi:10.1186/ s13044-018-0047-8. eCollection 2018

Ultrasound criteria for risk stratification of thyroid nodules in the previously iodine deficient area of Austria - a single centre, retrospective analysis.

Tugendsam $C^{1}$, Petz $V^{2}$, Buchinger $W^{3}$, Schmoll-Hauer $B^{1,4}$, Schenk $I^{1,5}$, Rudolph $K^{1}$, Krebs $M^{1,6}$, Zettinig $G^{1}$.

1 Schilddruesenpraxis Josefstadt, Laudongasse 12/8, Vienna, AT-1080 Austria.

2 Division of Nuclear Medicine, Department of Biomedical Imaging and Image-guided Therapy, Medical University of Vienna, Vienna, Austria.

3 Schilddrueseninstitut Gleisdorf, Gleisdorf, Austria.

4 Department of Nuclear Medicine, Krankenanstalt Rudolfstiftung, Vienna, Austria.

5 Department of Nuclear Medicine, Sozialmedizinisches Zentrum Hietzing, Vienna, Austria.

6 Clinical Division of Endocrinology, Department of Medicine III, Medical University of Vienna, Vienna, Austria.

Background We aimed to study the validity of six published ultrasound criteria for risk stratification of thyroid nodules in the former severely iodine deficient population of Austria.

Methods Retrospective, single centre, observer blinded study design. All patients with a history of thyroidectomy due to nodules seen in the centre between 2004 and 2014 with preoperative in-house sonography and documented postoperative histology were analyzed $(n=195)$. A board of five experienced thyroidologists evaluated the images of 45 papillary carcinomas, 8 follicular carcinomas, and 142 benign nodules regarding the following criteria: mild hypoechogenicity, marked hypoechogenicity, microlobulated or irregular margins, microcalcifications, taller than wide shape, missing thin halo.
Results All criteria but mild hypoechogenicity were significantly more frequent in thyroid cancer than in benign nodules. The number of positive criteria was significantly higher in cancer $(2.79 \pm 1.35)$ than in benign nodules $(1.73 \pm 1.18 ; p<0.001)$. Thus, with a cut-off of two or more positive criteria, a sensitivity of $85 \%$ and a specificity of $45 \%$ were reached to predict malignancy in this sample of thyroid nodules. As expected, the findings were even more pronounced in papillary cancer only (2.98 \pm 1.32 vs. $1.73 \pm 1.18, p<0.001)$. The six ultrasound criteria could not identify follicular cancer.

Conclusion Our findings support the recently published EU-TIRADS score. Apart from mild hypoechogenicity, the analyzed ultrasound criteria can be applied for risk stratification of thyroid nodules in the previously severely iodine deficient population of Austria.

Pediatr Radiol. 2018 May 23. doi:10.1007/ s00247-018-4147-3 [Epub ahead of print]

European Society of Paediatric Radiology Abdominal Imaging Task Force recommendations in paediatric uroradiology, part $\mathrm{X}$ : how to perform paediatric gastrointestinal ultrasonography, use gadolinium as a contrast agent in children, follow up paediatric testicular microlithiasis, and an update on paediatric contrast-enhanced ultrasound.

Riccabona $\mathrm{M}^{1}$, Lobo $\mathrm{ML}^{2}$, Augdal $\mathrm{TA}^{3}$, Avni $\mathrm{F}^{4}$, Blickman $J^{5}$, Bruno $C^{6}$, Damasio $M B^{7}$, Darge $K^{8}$, Mentzel $H J^{9}$, Napolitano $M^{10}$, Ntoulia $A^{11}$, Papadopoulou $\mathrm{F}^{12}$, Petit $\mathrm{P}^{13}$, Woźniak $\mathrm{MM}^{14}$, Ording-Müller $L S^{15}$.

1 Department of Radiology, Division of Pediatric Radiology, University Hospital LKH Graz, Auenbruggerplatz 34, A-8036, Graz, Austriamichael.riccabona@klinikumgraz.at.

2 Department of Radiology, Hospital de Santa Maria-CHLN, University Hospital, Lisbon, Portugal

3 Department of Radiology, University Hospital of North Norway, Tromsø, Norway

4 Department of Pediatric Radiology, Jeanne de Flandre Hospital, CHRU de Lille, Lille Cedex, France
5 Department of Radiology, Golisano Children's Hospital, Rochester, NY, USA

6 Department of Radiology, AOUI, Verona, Italy

7 Department of Radiology, G. Gaslini Institute, Genoa, Italy

8 Department of Radiology, The Children's Hospital of Philadelphia, University of Pennsylvania, Philadelphia, PA, USA

9 Section of Pediatric Radiology, Institute of Diagnostic and Interventional Radiology, University Hospital, Jena, Germany

10 Department of Paediatric Radiology and Neuroradiology, V. Buzzi Children's Hospital, Milan, Italy

11 Department of Radiology, Poole Hospital NHS Foundation Trust, Poole, UK

12 Pediatric Ultrasound Center, Thessaloniki, Greece

13 Hôpital Timone Enfants, Service d'Imagerie Pédiatrique et Prénatale, Marseille, France

14 Department of Pediatric Radiology, Medical University of Lublin, Lublin, Poland 15 Department of Radiology and Nuclear Medicine, Unit for Paediatric Radiology, Oslo University Hospital, Oslo, Norway.

At the European Society of Paediatric Radiology (ESPR) annual meeting 2017 in Davos, Switzerland, the ESPR Abdominal (gastrointestinal and genitourinary) Imaging Task Force set out to complete the suggestions for paediatric abdominal imaging and its procedural recommendations. Some final topics were addressed including how to perform paediatric gastrointestinal ultrasonography. Based on the recent approval of ultrasound (US) contrast agents for paediatric use, important aspects of paediatric contrast-enhanced US were revisited. Additionally, the recent developments concerning the use and possible brain deposition of gadolinium as a magnetic resonance imaging contrast agent were presented. The recommendations for paediatric use were reissued after considering all available evidence. Recent insights on the incidence of neoplastic lesions in children with testicular microlithiasis were discussed and led to a slightly altered recommendation.

Ausbildung zum „StudentInnen-Tutor“ mit ÖGUM-Zertifikat

Die ÖGUM hat ein Ausbildungsprojekt gestartet, um engagierten Studentinnen 
und Studenten, die sich für die UltraschallBildgebung \& -anwendung interessieren, eine Ausbildung auf ÖGUM -zertifiziertem Sonografie-Niveau anzubieten und diese zu fördern. Bei erfolgreichem Abschluss wird der Titel „zertifizierter ÖGUM-StudentInnen-Tutor" verliehen.

\section{... Erwerb der ÖGUM-Zusatzqualifikation}

(1) Studierende ab 2. Studienjahr sind zugelassen.

(2) Absolviertes Wahlfach „Ultraschall“ (z. B. Abdomen) an einer österr. MedizinUniversität oder absolvierter Fortbildungsgrundkurs der ÖGUM.

(3) Technische Basiskenntnisse der klassischen Ultraschalltechniken sowie Sicherheitsaspekte, potenzielle Bioeffekte \& Artefakte.

(4) Aktive ÖGUM-Mitgliedschaft als Student.

\section{... Benefit für Studierende mit ÖGUM- Zusatzqualifikation}

- Nennung auf der ÖGUM-Website als qualifizierter Tutor.

- Kostenloser Eintritt auf 3-Ländertreffen in Österreich.

- Teilnahme an einem Anwenderseminar (AWS) auf einem 3-Ländertreffen in Österreich.

- Mitarbeit in der Sono-Höhle als SonoTutor und/oder Hands-On-Modell (Planung \& Tutor-Tätigkeit ist nur ÖGUM-Studenten-Tutoren vorbehalten).

- Mitarbeit in entsprechenden Arbeitskreisen als Student.

- Zugang zu internen Mitgliederinformationen (z. B. Online-Zeitschrift).

- Knüpfung neuer fachlicher Kontakte.

- Profitieren von Experten-Erfahrungen.

- Sonografie-Ausbildung nach ÖGUMRichtlinien.

- Dokumentation der erworbenen fachlichen Kompetenz an der Heimatuniversität und Skills-Labs durch das ÖGUMZertifikat.
... Ausübung der ÖGUM-Studenten-TutorTätigkeit:

- Auf dem nächstfolgenden DLT nach Zertifikats-Verleihung und aktiver Anmeldung als Tutor-Teilnehmer.

- Auf zukünftigen DLTs durch Nachweis von einschlägigen Fortbildungen und aktiver Anmeldung als Tutor-Teilnehmer und aufrechter ÖGUM-Mitgliedschaft.

Siehe auch: http://www.oegum.at/ausbildung/studentinnen-tutor.html

\section{Kursbericht}

\section{ÖGUM-zertifizierter Notfallsonografie-Kurs}

Vom 9.-10. Juni hat die Tiroler Arbeitsgemeinschaft für Notfallmedizin einen ÖGUM-zertifizierten Notfallsonografie-Kurs abgehalten. Durch die unterschiedlichen medizinischen Disziplinen der Organisatoren wurde die Einsatzmöglichkeit der Sonografie in der Notfallmedizin von den verschiedensten Blickwinkeln beleuchtet. Der Workshop wurde wieder im Thermen- und Kongresshotel Aquadome, Längenfeld im Ötztal, abgehalten. Der Kurs war aus didaktischen Gründen auf 40 Teilnehmer beschränkt und ausgebucht.

Mit Prof. Gebhard Mathis (ÖGUM-Arbeitskreisleiter Notfallsonografie) sowie Prof. Joseph Osterwalder konnten wir 2 Pioniere der Notfallsonografie für spannende Vorträge sowie als Tutoren gewinnen. Dankenswerterweise haben wieder zahlreiche namhafte Ultraschallgerätehersteller sowie weitere Sponsoren die Veranstaltung unterstützt.

In Kleingruppen von je 5 Teilnehmern wurden durch erfahrene Tutoren die Notfallsonografie sowie die fokussierte Echokardiografie an Probanden trainiert. Auch die sonografisch gezielte Punktion wurde den Teilnehmern nähergebracht und konnte an einem Phantom geübt werden. Des Weiteren stand uns auch ein Gerät zur „Sonografie-Simulation“ zur Verfügung. Damit war es uns erstmals möglich, verschiedenste Pathologien an Probanden bzw. Dummies zu simulieren und konnten somit die Attraktivität des Kurses noch deutlich steigern.

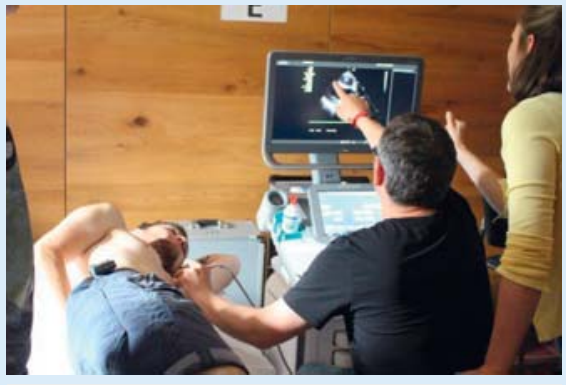

Fokussierte Echokardiografie.

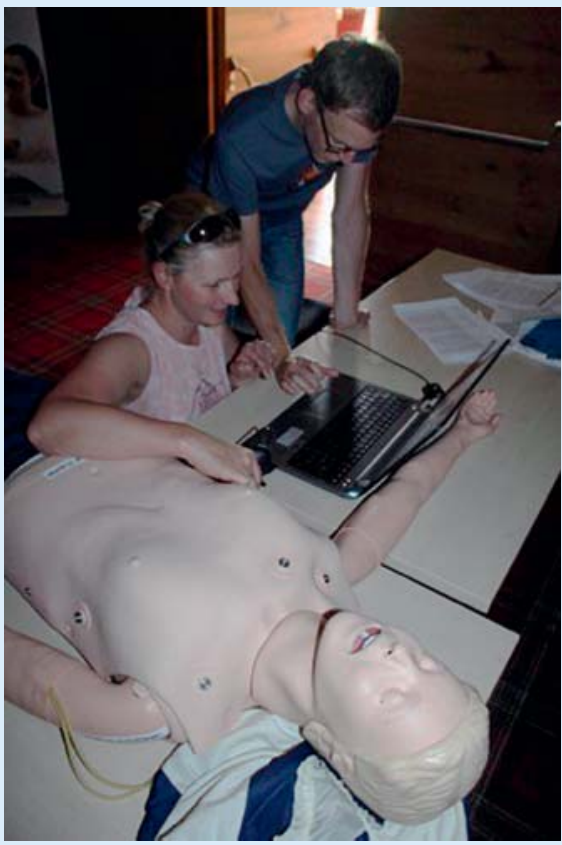

Sono-Simulation am „Probanden“ - einer normalen Reanimationspuppe.

Die überaus positiven Rückmeldungen der Teilnehmer machen uns stolz und sind uns gleichzeitig auch Motivation, im Jahr 2020 wieder einen Notfallsonografie-Kurs in Tirol abzuhalten.

Im nächsten Jahr organisieren wir die Oberländer Notfalltage (www.notfalltage.at), einen 2-tägigen Notarzt-Refresher-Kurs. Auch bei dieser Veranstaltung wird eine Praxisstation der präklinischen Notfallsonografie gewidmet werden.

Dr. Ralph Faschingbauer

ÖGUM-Kursleiter Notfallsonografie 